\title{
THE BINDING OF SULFONAMIDE DRUGS BY PLASMA PROTEINS. A FACTOR IN DETERMINING THE DISTRIBUTION OF DRUGS IN THE BODY
}

\author{
By BERNARD D. DAVIS 1 \\ (From the Chemical Division of the Department of Medicine, Johns Hopkins Hospital, Baltimore, \\ and the Division of Industrial Hygiene, National Institute of Health, U. S. Public \\ Health Service, Bethesda, Maryland)
}

(Received for publication April 5, 1943)

An assumed difference in diffusibility of various sulfonamide drugs into the cerebrospinal fluid has been widely invoked to explain the low cerebrospinal fluid levels of certain drugs, especially sulfathiazole. In a preliminary report (1), it was pointed out that certain facts regarding the distribution of these drugs in the body may be explained by their binding to proteins in the body fluids.

In this paper, there is presented a brief nonmathematical discussion of the concepts of diffusibility and permeability, as they relate to the distribution of substances in the body fluids, assumed to be separated by a series of semipermeable membranes. According to the principles here described, it is deduced from the observed distribution of sulfonamide drugs that these molecules are bound to plasma proteins. Experiments are reported which confirm this expectation. Further experiments are reported concerning the effect on this binding of $\mathrm{pH}$, temperature, and fractionation of the proteins, the purpose of which is to furnish information concerning the nature of the binding, and to insure that the findings are applicable to conditions in the body. Therapeutic implications are briefly discussed.

\section{PHYSICO-CHEMICAL CONSIDERATIONS}

The use of the term "diffusibility" by the clinician is sometimes incompatible with its physical definition, and is confused with the concept of permeability. Diffusion in a solution refers to the process of spontaneous thermal agitation of the molecules, which causes a net transfer from regions of higher to regions of lower concentration without mixing by flow.

1 Emmanuel Libman Fellow in Medicine, Johns Hopkins University, 1941-42. Present address: Neurological Institute, College of Physicians and Surgeons, New York, N. $\mathbf{Y}$.
The diffusion constant refers to the rate of such transfer across a given concentration gradient, which, in a solution of constant temperature and viscosity, depends upon the size and shape of the molecules. Rate of diffusion decreases with increasing molecular weight. It may be expected to play an important role in the body in the distribution of two classes of substances: (1) those which are being rapidly transported in either direction between tissue cells and plasma, due to cellular metabolism, and (2) those with a fluctuating blood level, due to variations in absorption, excretion, and metabolic conversion. As an example of the first class, true diffusion undoubtedly is a major factor in governing the transfer of oxygen across the intercellular fluid, from capillary to tissue cell, for the molecule is small and the concentration gradient steep. The members of the second class, substances with fluctuating blood levels, are legion.

In cases of distribution across a membrane, many observed phenomena may be explained in terms of permeability rather than diffusibility. Permeability refers to the ability of the molecules to pass through the intervening membrane, whether impelled by forces of flow or of diffusion. In a flowing system, true equilibrium may not be reached and the composition of the filtrate may be considered to be determined by the rate of flow and the relative proportion of "pores" which permit or prevent passage of the large molecules along with the water and electrolytes. An example of permeation through flow is the distribution of proteins between plasma, interstitial fluid, and cerebrospinal fluid.

In the case of permeation by diffusion, in a system which is permitted to reach equilibrium, permeability is an all-or-none phenomenon-a component of the solution which could pass through any portion of the membrane would 
eventually be so distributed that on both sides of the membrane it would have the same thermodynamic activity. ${ }^{2}$ A difference in concentration between the fluids on the two sides of the membrane must be due to total impermeability of the component, or to factors which alter the ratio of activity to concentration, or to the existence of part of the component in an impermeable state. A well-known example of this latter phenomenon is the fact that only part of the calcium of serum is diffusible, the rest being bound to protein.

\section{APPLICATION TO THE PROBLEM OF DRUG DISTRIBUTION IN THE BODY}

This discussion of the principles of permeability obviously does not apply to those body fluids which are products of active secretion. We do consider that it applies to distribution of substances between plasma, red cells, fluid accumulations in body cavities and interstitial spaces, and cerebrospinal fluid. While cerebrospinal fluid is not a true dialysate of plasma, the observed deviations from such a state are of a lower order of magnitude than would be necessary to account for the distribution of sulfonamide drugs.

The facts of the distribution of sulfonamide drugs in the human body, as reported by Sadusk and coworkers $(2,3)$ and others (4 to 6$)$, are essentially the following. When a large dose of sulfapyridine, sulfadiazine, or sulfathiazole is

2 In dealing with equilibria of solutions, physical chemists express deviations from ideal behavior, in which concentrations fail to correspond to activities, by means of a correction factor which is called an activity-coefficient. The laws of chemical equilibria are formulated in terms of thermodynamic activities rather than chemical concentrations. In determining the extent of binding of sulfonamides to proteins, we assume that the activity coefficient is the same on the two sides of the membrane, and hence may be neglected. Actually, the distributions here observed may be formally treated as an effect of the protein on the activity coefficient of the sulfonamides, assuming no binding. These two alternative modes of formulation really describe the same phenomenon.

Asymmetrical distribution across a membrane of permeable ionized substances in the presence of other impermeable ions may also be accounted for by the Donnan effect. This, however, is no exception to the requirement of equality of activity on the two sides of the membrane, if the activity of a salt rather than of individual ions is considered. It will be shown later that the Donnan effect cannot account for the distributions here reported. given orally, the concentration in the blood reaches a peak in 2 to 4 hours. If frequent doses are then given in order to maintain the concentration in the blood as nearly level as possible, it is found that the concentration in the cerebrospinal fluid gradually rises and becomes more or less constant for all of the drugs after 24 hours. The rate of rise (in terms of proportion of its final level) appears in Sadusk's figures to be roughly the same for each of the three drugs. The levels reached, however, are quite different, the cerebrospinal fluid concentration of sulfathiazole averaging 25 per cent, sulfadiazine 50 per cent, and sulfapyridine 60 per cent of the respective blood level. For sulfanilamide, Sadusk (2) and Strauss (4) state that it resembles sulfapyridine in distribution and Katzenelbogen (6a) reported cerebrospinal fluid levels which were 60 to 90 per cent of the blood levels. Although data are not available on the rate of adjustment between blood and ascitic or pleural fluids, data on relative concentrations of sulfathiazole after several days of treatment show similar but smaller differences between blood and these extravascular fluids (2). The pleural fluid concentrations tended to approach the values found in blood more closely than did the ascitic fluids. Sulfadiazine also showed a level in these exudates, intermediate between its concentration in blood and in spinal fluid (3). The individual variation of all these distributions from the average was very large, probably because the blood level taken at the time of removal of fluid did not necessarily represent an average of the blood level during the time of equilibration with the fluid. It may be noted that, although the protein concentrations of these various fluids were not recorded, it is well known that pleural exudates generally have a higher protein content than peritoneal fluids, while the protein concentration of cerebrospinal fluid is negligible.

Interpreting these facts on the basis of the principles outlined above, it is apparent that the diffusibility of the drugs affects the rate at which the extravascular fluids reach equilibrium with the blood stream, but plays no role in determining that equilibrium. ${ }^{8}$ Differences in permeability, like-

\footnotetext{
3 It has been demonstrated experimentally (7) that the four sulfonamide drugs under discussion exhibit very similar rates of diffusion into gelatin gels. This might
} 
wise, can hardly account for the observed differences between blood and the other fluids, since these molecules are so small, and since some of the body fluids discussed (serous effusions) are in relatively static equilibrium with plasma, so that permeation by flow cannot be important. The fact that, for a given drug, the concentration in the various fluids appears to vary directly with their protein contents, suggests that the explanation lies in the binding of some of the sulfonamide molecules to protein molecules. There would thus be an equilibrium between bound and unbound molecules within each fluid, and since only the unbound molecules would be permeable, the concentration of unbound molecules would be the same in all fluids which were in equilibrium with each other. In the experiments reported below, this binding to protein was studied by equilibration between plasma and buffer through a membrane which was known to be permeable to sulfonamides but completely impermeable to the proteins. ${ }^{4}$

be expected from their similarity of molecular weight. Davenport (8a), however, has shown that these substances do differ in their rates of diffusion from the blood stream of the dog, and that these in vivo diffusion constants play a role in determining the concentration of the drugs in the gastric juice. This does not vitiate our argument, for gastric juice is a rapidly secreted fluid which cannot be expected to approach equilibrium with blood. It is interesting that the order of decreasing diffusibility for the four drugs, reported by Davenport, is identical with the order of increasing binding recorded here. We suggest that the discrepancy between the in vivo and in vitro diffusibility of the drugs may be at least partly accounted for by the assumption that only the unbound portion in the blood stream is freely diffusible, and that as this diffuses out of the capillary, it is constantly replenished by the reserve of bound drug. Even though the rate of equilibration between bound and unbound drug is probably extremely rapid, the concentration gradient, to which the rate of diffusion is proportional, is kept low by the binding of the drug.

4 Shannon (8b) has recently found in animal experiments that certain of the experimental sulfonamide drugs, not at present in clinical use, actually do not appear to be able to permeate the blood-brain-barrier, since their very low concentrations in spinal fluid and brain tissue cannot be explained by the degree of binding to plasma proteins, and yet they are found in adequate concentrations in other extravascular tissues. It follows that one may not apply to all sulfonamide compounds the concepts which are presented here on the basis of experience with four such drugs.

\section{METHODS}

All experiments were performed with a lot of human plasma which had been shown by electrophoresis to have a normal distribution of protein components. Five ml. of plasma were dialyzed at refrigerator temperature in a cellophane bag against $50 \mathrm{ml}$. of buffered drug solution until equilibrium was reached, which required 24 hours when the solutions were shaken, or 48 hours without shaking. Evidence that the time of equilibration was adequate was secured through two types of observation: (1) equilibration for an additional 24 hours caused no change in the concentration of drug on either side of the membrane, and (2) a bag of plasma containing a high concentration of drug and one containing no drug were dialyzed in the same vessel against a buffer solution; after the usual period of equilibration the concentrations within the two bags were identical. In all experiments recorded below, the drug was added only to the buffer solution; consequently, any inadequacy of equilibration would have resulted in too low rather than too high a plasma concentration and therefore too low an estimate of the degree of binding.

The buffer, designed to simulate body fluids, contained $0.15 \mathrm{M} \mathrm{NaCl}$ in $0.01 \mathrm{M}$ phosphate buffer, adjusted to $\mathrm{pH} 7.4\left(25^{\circ} \mathrm{C}\right.$.). In the experiments designed to study the effect of $\mathrm{pH}$, this was varied by additions of $\mathrm{HCl}$ or $\mathrm{NaOH}$, and the $\mathrm{pH}$ determined with the Beckmann $\mathrm{pH}$ meter at room temperature. To eliminate the possibility of an effect by the dilute phosphate buffer on the distribution of the drug, in one experiment, $5 \mathrm{ml}$. of 0.9 per cent saline were dialyzed against $50 \mathrm{ml}$. of plasma, reversing the usual volumes and thus allowing the plasma to buffer itself; the saline, which became during the dialysis essentially a dialysate of the plasma, showed the same distribution coefficient against plasma as did the phosphate buffer in the usual experiment.

Protein concentrations were determined by macroKjeldahl analyses, using a factor of 6.25 to convert nitrogen values to protein. Since the plasma was dialyzed against 10 times its volume of buffer, the non-protein nitrogen, including the small additions of sulfonamide nitrogen, was neglected. Because the colloid osmotic pressure of the protein caused a variable increase in the volume of fluid within the bag, a protein analysis was performed in each case, even though the initial concentrations were the same. Sulfonamides were analyzed according to the method of Bratton and Marshall (9), using a photoelectric colorimeter. It was verified for several of the drugs that the trichloroacetic acid filtrate of serum gave 98 to 100 per cent recovery of added sulfonamide.

\section{CaLCULATIONS}

In analyzing the data, the assumption is made that the concentrations of sulfonamide present in the buffer solution and the plasma would be proportional to their respective water contents were it not for the present of a nondialyzable constituent in the plasma to which drug is bound. Since the volume per gram of plasma proteins in 
solution is approximately $0.75 \mathrm{ml}$., the water content of the plasma is estimated to be lower than that of the buffer by a factor of 0.75 times the protein concentration; the correction is small. Plasma water multiplied by the concentration of the drug in the buffer is taken to be the concentration of the unbound drug in the plasma; the difference between this and the concentration found in the plasma is considered bound drug. The ratio of bound to unbound drug, divided by the protein concentration in grams per cent, forms the last column in the tables, and is a measure of the "affinity" of sulfonamide for protein. This calculation of the ratio of bound to unbound drug is employed for purposes of analysis of the chemical equilibria, although from the point of view of distribution in the body, it is the ratio of unbound to total which is significant.5

To illustrate the calculations-in one experiment, the concentration of sulfathiazole in the buffer was $6.0 \times$ $10^{-4} \mathrm{M}$, while that in the plasma was $15.2 \times 10^{-4} \mathrm{M}$; the protein content of the plasma was 5.94 per cent. The water content of the plasma is calculated as $100-(5.94$ $\times 0.75)=95.5$ per cent of the water content of the buffer. The unbound plasma drug is therefore $0.955 \times$ $6.0 \times 10^{-4}=5.7 \times 10^{-4} \mathrm{M}$; the bound drug is $(15.2-5.7)$ $\times 10^{-4}=9.5 \times 10^{-4} \mathrm{M}$. Dividing $9.5 \times 10^{-4}$ by $6.0 \times 10^{-4}$ gives 1.58 , or 158 per cent as the ratio of bound to free drug; dividing this by 5.94 per cent protein gives 27 per cent as the ratio bound per gram of protein, expressed in per cent.

\section{RESULTS}

\section{Effect of drug concentration}

Data relating to the binding to serum of four sulfonamide drugs at $\mathrm{pH} 7.4$ are included in Table I and Figure 1. It may be noted that the extent of binding increases in this order,-sulfanilamide, sulfapyridine, sulfadiazine, and sulfathiazole. As the concentration of a drug is increased, the proportion bound decreases; consequently, in comparing the binding of various compounds, it is necessary to use the same range of concentrations.

5 In calculating the bound drug as the difference in concentration between the plasma and its dialysate, the effect of the Donnan equilibrium was neglected. In the case of plasma, this effect causes the concentration of a permeable monovalent anion to be approximately 10 per cent less in the plasma than in the dialysate. Since those sulfonamides which are largely ionized at $\mathrm{pH} 7.4$ (see below) are also the most extensively bound, the Donnan effect is negligible in comparison with the binding; in the case of sulfathiazole, the plasma level is 300 per cent greater than that of the dialysate. Any error arising from this neglect is in the direction of understimating the binding.
TABLE I

Binding to plasma at $\mathrm{pH} 7.4$

\begin{tabular}{|c|c|c|c|c|}
\hline \multirow{2}{*}{ Drug } & \multicolumn{2}{|c|}{ Concentration } & \multirow{2}{*}{ Protein } & \multirow{2}{*}{$\begin{array}{l}\text { Ratio of } \\
\text { bound to } \\
\text { free drug } \\
\text { per gram } \\
\text { protein }\end{array}$} \\
\hline & Buffer & Plasma & & \\
\hline & $M \times 10^{-4}$ & $M \times 10^{-4}$ & $\underset{\text { per cent }}{\text { grams }}$ & per cent \\
\hline Sulfanilamide & $\begin{array}{r}1.4 \\
2.7 \\
5.1 \\
11.0 \\
21.0\end{array}$ & $\begin{array}{c}1.7 \\
3.25 \\
6.5 \\
13.2 \\
22.6\end{array}$ & $\begin{array}{l}6.19 \\
6.20 \\
5.99 \\
6.44 \\
6.18\end{array}$ & $\begin{array}{l}4.6 \\
4.2 \\
5.3 \\
3.9 \\
2.1\end{array}$ \\
\hline Sulfapyridine & $\begin{array}{l}0.52 \\
1.15 \\
2.5 \\
4.7 \\
9.8\end{array}$ & $\begin{array}{l}0.96 \\
2.2 \\
3.8 \\
7.4 \\
14.5\end{array}$ & $\begin{array}{l}5.88 \\
6.13 \\
5.78 \\
6.06 \\
5.98\end{array}$ & $\begin{array}{r}15 \\
11 \\
10 \\
10 \\
9\end{array}$ \\
\hline Sulfadiazine & $\begin{array}{c}0.48 \\
1.25 \\
3.4 \\
6.2 \\
10.7\end{array}$ & $\begin{array}{r}1.2 \\
2.7 \\
6.3 \\
11.0 \\
18.0\end{array}$ & $\begin{array}{l}5.76 \\
5.80 \\
6.36 \\
6.13 \\
6.02\end{array}$ & $\begin{array}{l}27 \\
21 \\
15 \\
14 \\
12\end{array}$ \\
\hline Sulfathiazole & $\begin{array}{r}1.4 \\
3.0 \\
6.0 \\
12.1\end{array}$ & $\begin{array}{r}5.3 \\
9.9 \\
15.2 \\
28.1\end{array}$ & $\begin{array}{l}5.94 \\
6.38 \\
5.94 \\
6.00\end{array}$ & $\begin{array}{l}48 \\
37 \\
26 \\
23\end{array}$ \\
\hline
\end{tabular}

\section{Effect of protein concentration}

Table II presents the results of a series of dilutions of plasma, simultaneously dialyzed in a single vessel containing a drug in buffer solution. It is noted that the percentage bound per gram decreases with decreasing protein concentration. This effect is small, however, so that it appears permissible to compare the binding power per gram of protein solutions which vary quite appreciably in protein concentration.

\section{Effect of temperature}

Because the solutions became cloudy at room temperature, the equilibrations were performed in a refrigerator, under which conditions they remained clear. The data in Table III show that the effect of temperature on the equilibrium is slight, and that the data obtained are applicable to conditions at body temperature.

\section{Binding to protein fractions}

A liter of human serum was separated into fractions according to the technique of McMeekin (10), consisting of gradual additions of $\left(\mathrm{NH}_{4}\right)_{2} \mathrm{SO}_{4}$ through rotating cellophane bags; the precipitate filtered off after each addition was 


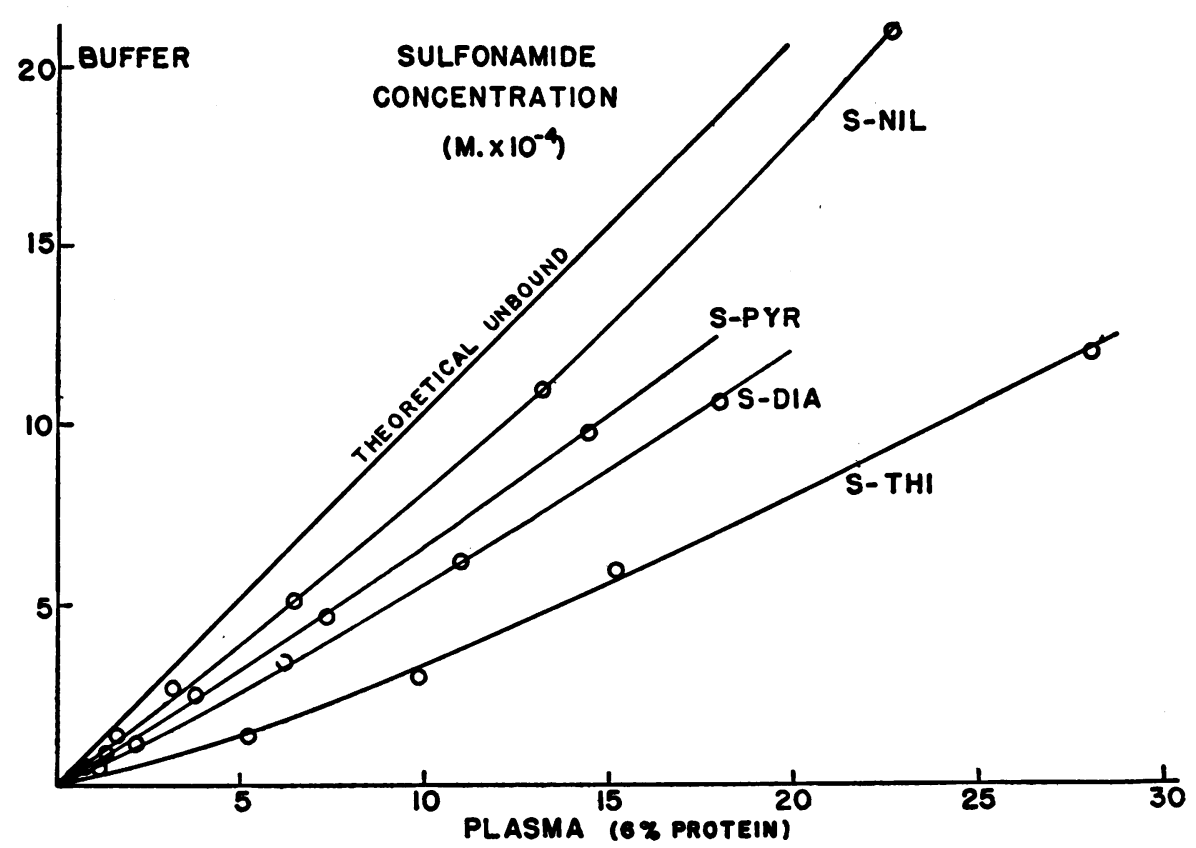

Fig. 1. Concentration of Sulfanilamide, Sulfapyridine, Sulfadiazine, and Sulfathiazole in Plasma and Saline-Phosphate (pH 7.4) Which Have Been Equilibrated Against Each Other by Dialysis

dissolved in an arbitrary volume of water, dialyzed against running tap water until essentially $\mathrm{NH}_{3}$-free and then dialyzed against buffer. The various fractions were analyzed on the $\mathrm{Ti}$ selius electrophoresis apparatus for their composition of albumin and globulins, using barbital buffer at $\mathrm{pH}$ 8.5. It is seen from the data in Table IV that the binding of sulfathiazole to the various fractions parallels their albumin content; there is practically no binding to globulins.

TABLE II

Binding to dilutions of plasma at pH 7.4

\begin{tabular}{|c|c|c|c|c|}
\hline \multirow{2}{*}{ Drug } & \multicolumn{2}{|c|}{ Concentration } & \multirow{2}{*}{ Protein } & \multirow{2}{*}{$\begin{array}{l}\text { Ratio of } \\
\text { bound to } \\
\text { free drug } \\
\text { per gram } \\
\text { protein }\end{array}$} \\
\hline & Buffer & Plasma & & \\
\hline & $M \times 10^{-4}$ & $M \times 10^{-4}$ & $\underset{\text { prams }}{\text { grant }}$ & per cent \\
\hline Sulfathiazole & 7.4 & $\begin{array}{l}23.8 \\
23.4 \\
19.4 \\
16.2 \\
11.6\end{array}$ & $\begin{array}{l}5.58 \\
5.31 \\
4.23 \\
3.09 \\
1.71\end{array}$ & $\begin{array}{l}40 \\
42 \\
39 \\
39 \\
34\end{array}$ \\
\hline Sulfadiazine & 9.8 & $\begin{array}{l}18.4 \\
15.8 \\
13.4 \\
11.6\end{array}$ & $\begin{array}{l}5.94 \\
4.88 \\
3.30 \\
1.88\end{array}$ & $\begin{array}{l}15 \\
13 \\
12 \\
10\end{array}$ \\
\hline
\end{tabular}

When sera are dialyzed or precipitated, the proteins are invariably accompanied by considerable lipoid in the form of lipoprotein complexes. To insure that the protein and not lipoid was responsible for the binding, a sample of plasma was precipitated by cold alcohol and washed with ether. Part of the resulting protein, which is assumed to be essentially lipoid-free, was denatured, but the soluble remainder showed binding of sulfathiazole of the usual order of magnitude.

The binding does not depend on the integrity of the native protein, for a specimen of horse serum which had been denatured by ultraviolet

TABLE III

Three similar sulfadiazine solutions dialyzed against plasma for 24 hours at different temperatures

\begin{tabular}{c|c|c|c}
\hline \multirow{2}{*}{$\begin{array}{c}\text { Temperature } \\
\text { ( C.) }\end{array}$} & Protein & \multicolumn{2}{|c}{ Sulfadiazine } \\
\cline { 2 - 4 } & & Plasma & Buffer \\
\hline & $\begin{array}{c}\text { grams } \\
\text { per cent } \\
5^{\circ} \text { (clear) }\end{array}$ & $M \times 10^{--}$ & $M \times 10^{-4}$ \\
$25^{\circ}$ (sl. cloudy) & 6.33 & 6.1 & 3.4 \\
$37^{\circ}$ (cloudy) & 6.04 & 5.4 & 3.1 \\
& 6.20 & 5.3 & 2.9 \\
\hline
\end{tabular}


TABLE IV

Binding of $1.35 \times 10^{-4} M$ sulfathiazole to serum protein fractions at $\mathrm{pH} 7.4$

\begin{tabular}{|c|c|c|c|c|c|c|c|}
\hline \multirow{2}{*}{ Fraction } & \multirow{2}{*}{$\begin{array}{c}\text { Pro- } \\
\text { tein }\end{array}$} & \multicolumn{5}{|c|}{$\begin{array}{l}\text { Electrophoretic percentage } \\
\text { of protein }\end{array}$} & \multirow{2}{*}{$\begin{array}{c}\text { Ratio of } \\
\text { bound } \\
\text { to free } \\
\text { drug } \\
\text { per } \\
\text { gram } \\
\text { protein }\end{array}$} \\
\hline & & A & $\mathbf{A}_{\mathbf{1}}$ & Alpha & Beta & Gamma & \\
\hline & $\begin{array}{l}\text { grams } \\
\text { per cent }\end{array}$ & & & & & & per cent \\
\hline $\begin{array}{l}\left.1.0 \mathrm{NH}_{4}\right)_{2} \mathrm{SO}_{1} \\
1.65 \\
2.28 \\
3.10 \\
3.8\end{array}$ & $\begin{array}{r}10.55 \\
5.56 \\
4.95 \\
6.37 \\
2.78\end{array}$ & $\begin{array}{r}3.0 \\
8.1 \\
22.0 \\
78.9 \\
47.1\end{array}$ & $\begin{array}{l}0 \\
3.1 \\
3.0 \\
3.9 \\
44.8\end{array}$ & $\begin{array}{c}0 \\
54.1 \\
65.0 \\
9.5 \\
8.1\end{array}$ & $\begin{array}{r}11.0 \\
16.4 \\
7.0 \\
7.8 \\
0\end{array}$ & $\begin{array}{c}86.0 \\
18.3 \\
3.0 \\
0 \\
0\end{array}$ & $\begin{array}{r}6 \\
8 \\
23 \\
46 \\
70\end{array}$ \\
\hline $\begin{array}{l}\text { Whole serum } \\
\text { "Albumin" } \\
\text { "Globulin" }\end{array}$ & $\begin{array}{l}5.74 \\
5.84 \\
8.25\end{array}$ & $\begin{array}{r}49.6 \\
77.8 \\
3.6\end{array}$ & $\begin{array}{l}4.1 \\
7.4 \\
2.3\end{array}$ & $\begin{array}{c}8.1 \\
0 \\
15.0\end{array}$ & $\begin{array}{l}14.2 \\
14.2 \\
13.7\end{array}$ & $\begin{array}{c}24.0 \\
0 \\
65.5\end{array}$ & $\begin{array}{r}37 \\
52 \\
8\end{array}$ \\
\hline
\end{tabular}

$A$ and $A_{1}$ designate albumin components, $A_{1}$ being the slower, very soluble component, which is visible at $\mathrm{pH} 8.5$ as here analyzed, but is not separated from $\mathrm{A}$ at $\mathrm{pH}$ 7.4. Alpha, Beta and Gamma are the usual globulin components. Binding appears to be particularly marked in the case of $A_{1}$. The bottom two fractions are the conventional so-called albumin and globulin separated by half-saturation $(2.05 \mathrm{M})$ with $\left(\mathrm{NH}_{4}\right)_{2} \mathrm{SO}_{4}$.

irradiation until its relative viscosity had increased to three times the original value (11) showed only slightly decreased binding of sulfathiazole.

\section{Distribution between red cells and plasma}

Portions of two different samples of citrated human blood were shaken overnight in the re-

TABLE V

Distribution of sulfonamide drugs between red cells and plasma

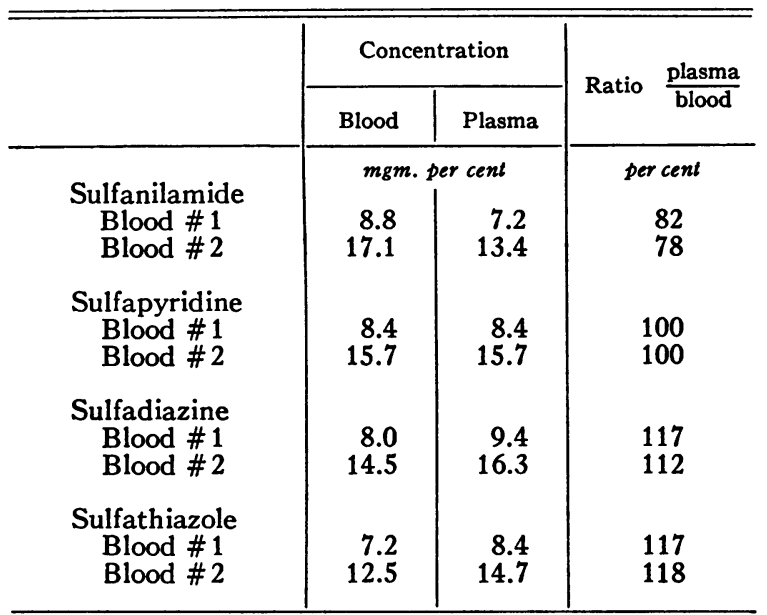

Blood \# 1: hematocrit 33.4 per cent, plasma protein $\mathbf{5 . 7 2}$ per cent.

Blood \# 2: hematocrit 37.0 per cent, plasma protein 6.25 per cent. frigerator after addition of one of the drugs. The results of the determination of the drug concentrations in the plasma and whole blood are given in Table V. To insure that equilibrium was reached under these conditions, one sample containing sulfanilamide was shaken for 24 hours more; the plasma level showed no significant change. It is seen that, for blood of 35 per cent red cell volume, the plasma concentration of sulfanilamide is 80 per cent of the whole blood value, while the plasma levels of sulfadiazine and sulfathiazole are 115 per cent of the blood levels. Sulfapyridine is equally distributed between red cells and plasma.

\section{Effect of hydrogen ion concentration}

When $\mathrm{pH}$ was varied from 6 to 8.5, all four drugs showed a decrease in binding with increasing acidity, but the form of the curves (Figure 2) was quite variable. Although our data do not extend into a very acid range, this tendency to decreased binding in acid solution suggests an explanation for the observation that complete re-

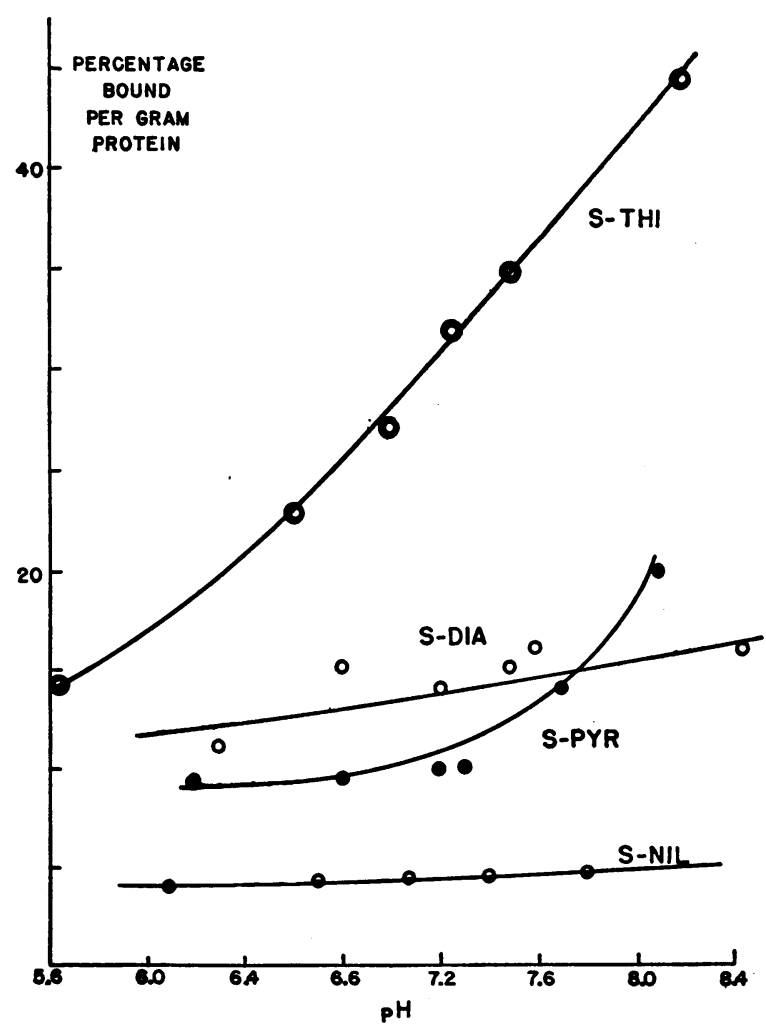

Fig. 2. Variation with $\mathrm{PH}$ of Binding of Four Sulfonamide Drugs to Plasma Protein 
coveries are obtained in the protein-free filtrates from trichloroacetic acid or toluenesulfonic acid, but not from the less acid tungstate filtrate (12). In addition to the data presented in the table, it was found that in $\mathrm{N} / 100 \mathrm{NaOH}$ ( $\mathrm{pH}$ approximately 12), there was no binding of sulfathiazole. A similar effect of $\mathrm{pH}$ on the binding of phenol red to serum has been reported (13).

\section{Ultraviolet absorption spectra}

In analogy with the well-known effect of proteins on the visible light absorption spectra of dyes, it was suggested by Professor W. M. Clark that sulfonamides, which do not absorb visible light, might give direct proof of chemical binding by showing an alteration of absorption in the ultraviolet range. This did not turn out to be the case in a mixture of sulfathiazole and serum al-

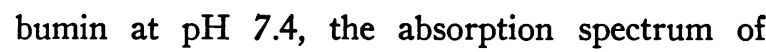
which was the sum of the spectra of the two components. ${ }^{6}$ This does not rule out direct binding, for such binding might take place at points on the molecules distant from the chromophore groups. Furthermore, absorption bands of solutions in the ultraviolet are so broad that slight shifts would be difficult to detect.

\section{DISCUSSION}

\section{Meçhanism of binding}

Bennhold (14), in an extensive monograph, concluded that the function of plasma proteins as carriers of small molecules is physiologically as important as their function in maintaining fluid balance by virtue of their colloid osmotic pressure. While this view has not received general acceptance, it is interesting to note the recent statement by Whipple (15) that "The old idea that plasma proteins are inert colloids which have to do with fluid equilibrium and little else is a real handicap to medical thought."

In the early days of protein chemistry, the binding of even alkalis and acids was considered due to adsorption; then following the work of Jaques Loeb (16) and others, emphasis was placed upon the stoichiometric aspects of the amphoteric behavior of proteins. Evidence from several sources, however, has shown that such interactions do not

- Ultraviolet absorption spectra were kindly furnished by Dr. Peter A. Cole. always obey the classical relations between $\mathrm{pH}$, $\mathrm{pK}$, ionic strength, and activity coefficients; the phenomena may be explained by the assumption that proteins combine reversibly not only with $\mathrm{H}^{+}$ and $\mathrm{OH}^{-}$ions, but also with simple anions or cations such as $\mathrm{Cl}^{-}$or $\mathrm{Ca}^{++}$. Such may be inferred from specific ion effect on titration curves (17, $18)$ and on electrophoretic mobility $(19,20)$ of proteins, and on the affinity of hemoglobin for oxygen (21). Binding of sulfonamides, therefore, introduces no new principle.

The interpretation of the effect of $\mathrm{pH}$ on binding is complicated by the fact that the ionization of both protein and drug varies with $\mathrm{pH}$. Inasmuch as binding increases with moderate alkalinity, one might suppose that it depends largely upon the negatively ionized groups of the protein; but this does not explain why binding should disappear in strongly alkaline solutions where the net negative charge on the protein molecule is maximal, unless a change takes place in the ionization of the drug in this alkaline region. This latter does not appear to be the case, for Fox and Rose (22) and Schmelkes et al. (23) have recently reported the acid-base dissociation constants of a series of sulfonamides to range from $\mathrm{pK} 10.5$ for sulfanilamide to 6.8 for sulfathiazole. At $\mathrm{pH} 7.4$, then, sulfathiazole would be ionized to a large extent and sulfanilamide very little, while at $\mathrm{pH} 12$, all the drugs would exist almost exclusively as anions. The order of decreasing $\mathrm{pK}$ (i.e., increasing concentration of anion at a given $\mathrm{pH}$ ) is identical with that of increasing binding. A larger series of seven sulfonamide drugs has been reported by Davis and Wood (24a) to demonstrate a parallelism between bacteriostatic potency, binding tendency to protein, and the pK's quoted above. However, Bell and Roblin (24b) have recently studied a very large series of sulfonamide drugs and found that the parallelism of bacteriostatic activity with $\mathrm{pK}$ holds only for compounds with $\mathrm{pK}$ above 6.2; compounds of greater acidity, although essentially completely ionized at $\mathrm{pH} 7.0$, are progressively less active with decreasing $\mathrm{pK}$. They explain these facts by the interesting hypothesis that the bacteriostatic activity is correlated primarily not with ionization, but with the negativity of the $\mathrm{SO}_{2}$ group. For the four compounds studied in the 
TABLE VI

Calculated distribution of sulfonamide drugs, at plasma levels of $10 \mathrm{mgm}$. per cent, between plasma of 6 per cent protein, its dialysate, and whole blood

\begin{tabular}{|c|c|c|c|c|c|c|}
\hline \multirow{2}{*}{ Drug } & \multirow{2}{*}{$\begin{array}{c}\text { Plasma } \\
\text { concentration } \\
\left(\mathrm{M} \times 10^{-4}\right)\end{array}$} & \multirow{2}{*}{$\begin{array}{l}\text { Ratio of bound to } \\
\text { free drug per } \\
\text { gram protein }\end{array}$} & \multirow{2}{*}{$\begin{array}{c}\text { Dialysate } \\
\text { concentration } \\
\left(\mathbf{M} \times 10^{-4}\right)\end{array}$} & \multicolumn{3}{|c|}{ Ratio: } \\
\hline & & & & $\frac{\text { Dialysate }}{\text { Plasma }}$ & $\frac{\text { Plasma }}{\text { Blood }}$ & $\frac{\text { Dialysate }}{\text { Blood }}$ \\
\hline $\begin{array}{l}\text { Sulfanilamide } \\
\text { Sulfapyridine } \\
\text { Sulfadiazine } \\
\text { Sulfathiazole }\end{array}$ & $\begin{array}{l}1.72 \\
2.50 \\
2.50 \\
2.50\end{array}$ & $\begin{array}{c}\text { per cent } \\
4.6 \\
10 \\
21 \\
55\end{array}$ & $\begin{array}{l}1.40 \\
1.61 \\
1.13 \\
0.59\end{array}$ & $\begin{array}{l}82 \\
64 \\
45 \\
24\end{array}$ & $\begin{array}{c}\text { per cent } \\
80 \\
100 \\
115 \\
117\end{array}$ & $\begin{array}{l}66 \\
64 \\
52 \\
28\end{array}$ \\
\hline
\end{tabular}

The calculated ratio for dialysate/blood corresponds very closely to the clinically observed ratios (see text) for cerebrospinal fluid/blood.

present paper, negativity of $\mathrm{SO}_{2}$ is parallel to and dependent on the ionization of the substituent attached to the $\mathrm{SO}_{2} \mathrm{NH}$-group, but the results reported in our earlier paper (24a) must be reinterpreted in the light of the concept of Bell and Roblin.

This correlation of binding with degree of anionic dissociation, or of $\mathrm{SO}_{2}$ negativity, suggests that binding may depend predominantly on electrostatic attraction to positively charged regions on the protein surface. This hypothesis can be reconciled with the observed increase and later disappearance of binding with increasing alkalinity, if we recall the well-established fact that proteins are "zwitterions"-that is, at the isoelectric point, they have a large and equal number of positive and negative charges, and with increasing alkalinity, a net negative charge is produced by depression of positive ionization. Hence, in strongly alkaline solution, all the drug and all the protein molecules would have only negative charges, and would repel each other, but in the intermediate range, binding would increase with alkalinity if the importance of the increasingly ionized drug outweighed that of the decreasing number of positive groups of the protein.?

\footnotetext{
7 The data of Table I, and Figure 1, in which the proportion bound decreases with increasing drug concentration, fit very well the empirical equation of the Freundlich adsorption isotherm, which expresses the relationships of many phenomena of adsorption due to Van der Waals forces. These data, however, cover only a narrow range of concentration and are so few that they could doubtless be represented by alternative formulations based on mass law equilibria, or even on binding by the directed valence forces of hydrogen bonds.
}

\section{Distribution of drugs in the body}

From the data on the degree of binding of the various drugs, there may be calculated the distribution to be expected between plasma and its dialysate. The results of these calculations are presented in Table VI. Since the degree of binding varies with the concentration of drug and plasma protein, a typical clinical condition is assumed, with $10 \mathrm{mgm}$. per cent drug, 6 per cent protein, and 35 per cent red cell volume. The ratio of bound to free drug is interpolated from Figure 1 ; the dialysate concentration of drug is estimated by recalculating the binding in terms of the ratio of free to total drug and correcting for the water content. Inasmuch as the clinical data on drug distribution, presented in the introduction, are comparisons between whole blood and body fluids, whereas the physico-chemical equilibration occurs between plasma and body fluids, it is necessary to correct for the differences between blood and plasma levels, which are taken from Table V. It is seen that the predicted distributions between blood and its dialysate are in excellent agreement with those reported for blood and cerebrospinal fluid which were quoted in the section on "Application to the problem of drug distribution in the body"-a spinal fluid/ blood ratio of 25 per cent for sulfathiazole, 50 per cent for sulfadiazine, 60 per cent for sulfapyridine, and 60 per cent or more for sulfanilamide.

Consistent with this explanation of distribution are the data reported for aqueous humor of the eye (25), an essentially protein-free fluid, which develops particularly low concentrations of sulfathiazole. Another phenomenon which is ex- 
plained by the binding is that of the increased solubility of the drugs in plasma compared with water or buffer (26) ; in fact, solubility is as valid a measure of thermodynamic activity as is the distribution across a semipermeable membrane, the two solutions being in equilibrium with the crystals in the one case, and with each other in the other case.

\section{Therapeutic implications}

It is of practical therapeutic interest to know whether the bacteriostatically effective concentration in the body is the total measured concentration or only the portion not bound to protein; if the latter, then the concentration of active drug is as high in the spinal fluid as in the plasma, and one might disregard the spinal fluid levels in choosing a drug for the treatment of meningitis. $A$ priori, one might expect this to be the case, if the binding is pictured as being on the surface of the large protein molecule, which would be less accessible to the bacteria than the small free drug molecule. ${ }^{8}$

The effect of protein binding on bacteriostasis was tested by determining the minimum bacteriostatic concentrations against $E$. coli, with parallel control tubes and tubes containing 3 per cent sterile human serum albumin. ${ }^{\circ}$ The albumin increased the rate of growth of the organism in the absence of any drug, which complicated the results, but in several sets of experiments, in the presence of serial dilutions of the drugs, the increase caused by albumin in the concentration of drug necessary for bacteriostasis was most marked for sulfathiazole and least marked for sulfanilamide, with sulfapyridine and sulfadiazine intermediate but quite variable. This order of inhibition of bacteriostasis is what would be expected on the assumption that the albumin-bound drug was ineffective; the albumin tubes were too irregular, however, to furnish elegant quantitative data.

\footnotetext{
8 Our data do not prove actual binding to the surface, but the more formal treatment in terms of chemical activity would lead to the same conclusions, for bacteriostasis at a critical concentration of drug undoubtedly depends on a chemical equilibrium which, like all other chemical equilibria, is established on the basis of activities rather than concentrations.

${ }^{9}$ The author is indebted to Dr. W. B. Wood, Jr., for the bacteriological experiments.
}

It is concluded that the protein-bound drug is probably ineffective. While the ultimate test of the relative efficacy of various drugs in meningitis is the clinical one, it should be approached without prejudices based on low spinal fluid levels. Sulfathiazole, which gives rise to the lowest spinal fluid concentrations of any of the drugs used, and, hence, has often been rejected in favor of the clinically more toxic sulfanilamide, has actually been used successfully in the treatment of meningococcus meningitis $(27,28)$.

\section{SUM MARY}

It is proposed that the distribution of drugs in the body fluids, often interpreted in terms of diffusibility or permeability, should be analyzed in terms of thermodynamic activity and binding to protein.

Equilibria of sulfonamide drugs, dialyzed between plasma or plasma protein fractions and buffer, show considerable binding of drug to albumin, the extent of which accounts for the distribution of the drugs in the body fluids and the increased solubility in plasma. The order of increasing binding tendency is sulfanilamide, sulfapyridine, sulfadiazine, sulfathiazole.

The binding increases with increasing alkalinity over the $\mathrm{pH}$ range 6.0 to 8.5 , suggesting that anionic dissociation of the sulfonamide is a factor in the binding.

It is probable that only the unbound drug is bacteriostatically active. The effective level of any of the sulfonamides in the cerebrospinal fluid would then be as great as that in the blood stream, suggesting that the ratio of the concentrations in spinal fluid and blood should not be used as a guide to the choice of a drug in the treatment of meningitis.

The author is indebted to Dr. Mary Buell and the members of the Chemical Laboratory of the Johns Hopkins Hospital for many of the analyses.

\section{BIBLIOGRAPHY}

1. Davis, B. D., Binding of sulfonamides by plasma proteins. Science, 1942, 95, 78.

2. Sadusk, J. F., Blake, F. G., and Seymour, A., Observations on the absorption, excretion, diffusion, and acetylation of sulfathiazole in man. Yale J. Biol. and Med., 1940, 12, 681. 
3. Sadusk, J. F., and Tredway, J. B., Observations on the absorption, excretion, diffusion, and acetylation of sulfadiazine in man. Yale J. Biol. and Med., 1941, 13, 539.

4. Strauss, E., Lowell, F. C., Taylor, F. H. L., and Finland, M., Observations on the absorption, excretion and distribution of sulfanilamide, sulfapyridine, sulfathiazole and sulfamethylthiazole. Ann. Int. Med., 1941, 14, 1360.

5. Reinhold, J. G., Flippin, H. F., Schwartz, L., and Domm, A. H., The absorption, distribution, and excretion of 2-sulfanilamido pyrimidine (sulfapyrimidine, sulfadiazine) in man. Am. J. M. Sc., 1941, 201, 106.

6. Cutting, W. C., and Sultan, E. H., Sulfonamides: Passage into spinal fluid and rectal absorption. Ann. Int. Med., 1942, 16, 708.

6a. Katzenelbogen, S., Cruvant, B. A., and Silverberg, C., The distribution of sulfanilamide between blood and cerebrospinal fluid with special reference to intraspinal treatment. Am. J. M. Sc., 1941, 201, 724.

7. Hawking, F., The rate of diffusion of sulphonamide compounds. Quart. J. Pharm. and Pharmacol., 1941, 14, 226.

8a. Davenport, H. W., The mechanism of the secretion of sulfonamide drugs in gastric juice. Yale J. Biol. and Med., 1942, 14, 589.

8b. Shannon, J. A., Paper read at the conference on Sulfonamides held by the N. Y. Acad. of Sciences, April 9, 1943; to be published in the Ann. N. Y. Acad. Sci.

9. Bratton, A. C., and Marshall, E. K., Jr., A new coupling component for sulfanilamide determination. J. Biol. Chem., 1939, 128, 537.

10. McMeekin, T. L., Serum albumin. I. The preparation and properties of crystalline horse serum albumin of constant solubility. J. Am. Chem. Soc., 1939, 61, 2884.

11. Davis, B. D., Hollaender, A., and Greenstein, J. P., Electrophoretic patterns, colloid osmotic pressure, and viscosity of serum denatured by ultraviolet radiation. J. Biol. Chem., 1942, 146, 663.

12. Marshall, E. K., Jr., Determination of sulfanilamide in blood and urine. J. Biol. Chem., 1937, 122, 263.

13. Robinson, H. W., and Hogden, C. G., The influence of serum proteins on the spectrophotometric absorption curve of phenol red in a phosphate buffer mixture. J. Biol. Chem., 1941, 137, 239.

14. Bennhold, H., Uber die Vehikelfunktion der Serumei- weisskörper. Ergebn. d. inn. Med. u. Kinderh., 1932, 42, 273.

15. Whipple, G. H., Hemoglobin and plasma proteins: Their production, utilization and interrelation. Am. J. M. Sc., 1942, 203, 477.

16. Loeb, J., Proteins and the Theory of Colloidal Behavior. McGraw-Hill, N. Y., 1922.

17. Steinhardt, J., Fugitt, C. H., and Harris, M., Relative affinities of the anions of strong acids for wool protein. J. Res. Nat. Bur. Standards, 1941, 26, 293.

18. Steinhardt, J., Participation of anions in the combination of proteins with acids. Ann. New York Acad. Sc., 1942, 41, 287.

19. Davis, B. D., and Cohn, E. J., The influence of ionic strength and $\mathrm{pH}$ on electrophoretic mobility. J. Am. Chem. Soc., 1939, 61, 2092.

20. Tiselius, A., and Svensson, H., The influence of electrolyte concentration on the electrophoretic mobility of egg albumin. Trans. Faraday Soc., 1940, 36, 16.

21. Sidwell, A. E., Jr., Munch, R. H., Barron, E. S. G., and Hogness, T. R., The salt effect on the hemoglobin-oxygen equilibrium. J. Biol. Chem., 1938, 123, 335.

22. Fox, C. L., Jr., and Rose, H. M., Ionization of sulfonamides. Proc. Soc. Exper. Biol. and Med., 1942, 50, 142.

23. Schmelkes, F. C., Wyss, O., Marks, H. C., Ludwig, B. J., and Strandskov, F. B., Mechanism of sulfonamide action. I. Acidic dissociation and antibacterial effect. Proc. Soc. Exper. Biol. and Med., 1942, 50, 145.

24a. Davis, B. D., and Wood, W. B., Jr., Studies on antibacterial action of sulfonamide drugs. III. Correlation of drug activity with binding to plasma proteins. Proc. Soc. Exper. Biol. and Med., 1942, $51,283$.

24b. Bell, P. H., and Roblin, R. O., Jr., Studies in chemotheropy. VII. A theory of the relation of structure to activity of sulfanilamide type compounds. J. Am. Chem. Soc., 1942, 64, 2905.

25. Liebman, S. D., and Newman, E. H., Distribution of sulfanilamide and its derivatives between blood and aqueous. Arch. Ophth., 1941, 26, 472.

26. Marshall, E. K., Jr., Personal communication.

27. Banks, H. S., Sulphathiazole in cerebrospinal fever. Lancet, 1941, 1, 104.

28. Hodes, H. L., and Strong, P. S., Treatment of meningococcic meningitis with sulfonamides. ${ }^{\prime}$ J. A. M. A., 1942, 119, 691 . 